\title{
Literature Review of the Flipped Classroom
}

\author{
Fei Deng \\ School of Foreign Languages, Sichuan University of Arts and Science, Dazhou, Sichuan, China
}

\begin{abstract}
On the basis of the brief history of the Flipped Classroom, this paper explains different scholars' definition of the Flipped Classroom. And then it introduces the theoretical basis, which is Benjamin Bloom's Mastery Learning, including core idea, processing procedures, evaluation, and the educational significance of Mastery Learning in the Flipped Classroom. After that the paper makes a comparative analysis between the Traditional Classroom and the Flipped Classroom. At last it reviews the previous studies on the Flipped Classroom abroad, theoretical and practical studies on Flipped Classroom at home.
\end{abstract}

Index Terms - flipped classroom, definition, theoretical basis, comparative analysis, literature review

\section{INTRODUCTION}

In 2000, American scholars Maureen Lage, Glenn Platt and Michael Treglia introduced the great teaching efforts through Flipped Classroom when they were teaching Introduction of Economy in Miami University. They put the conclusion in their thesis Inverting the Classroom: A Gateway to Creating an Inclusive Learning Environment. However, they did not put forward the terms: Flipped Classroom Mode or Flipped Teaching. Also in 2000, J.Wesley Baker published the thesis The Classroom Flip: Using Web Course Management Tools to Become the Guide by the Side in the $11^{\text {th }}$ International Teaching Conference. The scholars put forward the terms theoretically, while in 2007 two chemistry teachers named Aaron Sams and Jonathan Bergmann, started to record PPT through video software with voice in Colroado. They uploaded the videos to the Internet to help those who missed lessons. Before long, they started a more innovative attempt to let all the students gradually watch videos, listen to lectures at home. In class, teachers mainly help students with their difficulties, or provide help for the students having difficulties in experiments. With the development of Internet, the Flipped Classroom becomes popular in North America.

\section{The Definition of FlipPed ClassRoom}

The definition of the Flipped Classroom was first given by MaureenLage, Glenn Platt and Michael Treglia. "Inverting the classroom means that events that have traditionally taken place inside the classroom now take place outside the classroom and vice versa." (MaureenLage, Glenn Platt, Michael Treglia, 2000, p.32). "Invert" means "turn inside out or upside down", which has the similar meaning with the word "Flip".

In Dan Barrett's book How 'Flipping'the Classroom Can Improve the Traditional Lecture, he points out "the Flipped Classroom can apply to a large range of mixture educational methods in which students get prepared materials and then take part in structured in-class activities." (Dan Berrett, 2012, p.37)

Bryan Goodwin and Kirsten Miller (2013) think the Flipped Classroom makes the students learn tasks before class to spot the difficulties. The tasks all go through three similar procedures: first, before class all the students watch the teaching video designed by the teacher. Second, the students try to finish all the tasks given by the teacher. Third, all the students discuss with teacher or classmates through QQ platform to share the answers and write down those unsolved and difficult questions. Thus the students can work out the unsolved and difficult questions with classmates or teachers rather than get the basic information passively in class.

As the real proposers of the Flipped Classroom, Aaron Sams, Jonathan Bergmann (2013) consider it as a teaching method, which mainly proposes what is traditionally done in the classroom is now done at home, and that students do homework or do some classroom activities in the class.

From the previous studies, different scholars offer different definitions on the Flipped Classroom. However, there are some similarities in the previous definitions, which focus on the student-based approach and inverting the teaching procedure.

After learning the previous definitions of the Flipped Classroom, the author defines it as following: Flipped Classroom is a pedagogical method in which students learn new knowledge through short videos, podcasts, e-books as well as internet outside class and consolidate what they acquired through classroom activities with the help of classmates and teachers.

\section{The THEORETICAL BASIS OF FLIPPED ClASSROOM}

The theoretical basis of Flipped Classroom in this study is Benjamin Bloom's Mastery Learning. He is a contemporary renowned psychologist and an educator and a teacher in education department in Chicago University. The 
Mastery Learning is the product of development in American education during 1950s and 1960s. According to Mastery Learning, "if the learning conditions have met students' need, anyone can master all they require to know during teaching process." (Benjamin S. Bloom, 1986, p.43) Bloom put forward that if the teaching processed smoothly according to the teaching schedule, if all the problems they encountered have been offered a help, if all the students were provided enough time, if there's a standard for mastering, then all the students can learn well and most of them will have almost equal learning abilities, learning speed, learning motivation (Qu Baokui, 1988). On the basis of his learning theory and previous fruits, Bloom came up with the idea "teaching for mastery" and then Mastery Learning Theory. Bloom believes that all the students will be able to master the knowledge once provided enough conditions.

Bloom's Mastery Learning Theory is based on Carol's studying theory, which absorbed five variables. The five variables include studying time, learning perseverance, teaching quality, understanding ability and aptitude. Those factors influence one another, and finally affect the learning effects.

\section{A. The Core Ideas of Mastery Learning}

Probably more than $90 \%$ students can master the learning contents, and the teaching task is to find out the approach that students can acquire knowledge they are learning. This is the core idea of "teaching for mastery". Thus the educators must change the traditional teaching ideas, and establish a new student-based view.

Bloom advocates a new student-based view, and believes under the teachers' guidance, most students can learn professional knowledge well and improve studying motivation.

\section{B. The Processing Procedures of Mastery Learning}

Mastery Learning is not only a theory, an idea, but also a strategy. In the theory of Mastery Learning, Bloom comes up with the new conception of teaching assessment, including "diagnostic assessment", "formative assessment" and "summative assessment".

At the beginning of a new semester, "diagnostic assessment" is necessary. Diagnostic assessment means that teachers assess students' performance before teaching. Its purpose is not to label them "good" or "bad", but to find out students' needs, and promote their studies.

It is necessary to give students assessments at each stage in the teaching process. "Formative assessment" is to give feedback for both students and teachers. Bloom believes that essence of Mastery Learning lies in group teaching along with individually corrective assistance and frequent feedbacks (Benjamin S. Bloom, 1987). Feedbacks often show that how much students have grasped and how much yet to learn. Offering individually corrective assistance helps students get the main points they still need to know and then adjust teaching process. Bloom thinks that each unit properly includes two-week studying activities or 8-10 hours of in-class teaching. In junior grade of primary school, each unit only concludes about one-week teaching. But in a higher level it can last three or four weeks, the point is that keeping the studying time maximum and correcting time minimum (Benjamin S. Bloom, 1987).

Summative assessment is often given at the end of teaching. Its goal is to give students assessments and certificates or to prove teaching schedules to be useful (Benjamin S. Bloom, 1987). The assessment of every semester, every academic year or each unit, helps reach a more comprehensive assessment for students.

The three assessments form a teaching cycle step by step, which are fully penetrated by feedbacks and corrections. Teachers improve their teaching based on assessment in each stage, and provide individual guidance and assistance as well. Students find out problems in each stage, make up the drawbacks and are responsible for their study. They are the master of their study.

\section{The Evaluation of Mastery Learning}

It is a kind of new teaching view and student-based view, which is a totally new research method. It solved the biggest misunderstanding in education primarily, which was the normal distribution theory "give up the ordinary students to protect the outstanding students" and provided new approaches and ideas for improving teaching qualities. Before that, we are guided by the traditional teaching model that is perusing the performance of the outstanding students but ignore the development of the ordinary students.

Mastery Learning Theory was first put forward in America. As a teaching strategy and theory, it has its own limitations. For example, it focuses on basic theory, basic courses and other enclosed courses, and not useful for innovative courses. At the same time, there are some difficulties in the process of implementation. It takes too much time and energy to concentrate on feedbacks and correction. It can only guarantee most students general development. Mastery Learning can make students master and consolidate the knowledge, but to some degree it would ignore other abilities.

\section{The Educational Significance of Mastery Learning in the Flipped Classroom}

Firstly, Bloom's Mastery Learning Theory contributes to students' achieving learning goals (Zhang Futao, 2014). This theory emphasizes the importance of making all students finish the tasks. It aims to meet the learning needs of every student.

Secondly, Mastery Learning Theory pays attention to differences among students (Zhang Futao, 2014). When making learning goals, teachers take the individual differences into consideration. Teachers should choose different learning 
materials for different students. Also they should adopt different teaching methods in order to offer peculiar guidance and help to students.

Thirdly, Mastery Learning Theory is good for the students' psychological health (Zhang Futao, 2014). During the learning process, teachers hold a positive attitude towards everyone, believing that every student can make it. Teachers have confidence in their students' learning abilities, and in return students will gain confidence because of the expectations, which help trigger their inner motives and make progress in their learning. During the whole process of learning, students become interested in learning contents, they enjoy the happiness of learning, gain a sense of achievement and have their own thoughts further developed.

Lastly, Mastery Learning Theory also puts emphasis on the cooperative learning and communication between students and teachers (Zhang Futao, 2014). During this process, they communicate and discuss with each other. Also students help each other, which help cultivate the cooperative spirit and improve the relationship among them.

\section{The Comparison BetweEn Traditional Classroom AND FliPPED Classroom}

Some scholars make a comparative analysis between the Traditional Classroom and the Flipped Classroom from the perspective of the constituent elements of teaching modes. The aspects include: role of teachers, role of students, teaching methods in class, time distribution in class, teaching contents in class, application of teaching methods and teaching evaluation (Zhang Renxian, 2014). The result is as shown in table:

\begin{tabular}{|l|l|l|}
\hline & Traditional Classroom & Flipped Classroom \\
\hline Role of teachers & Master of knowledge and class & Instructor and stimulator \\
\hline Role of students & Passive learner & Active learner and researcher \\
\hline Teaching methods in class & $\begin{array}{l}\text { Teaching in class and doing homework } \\
\text { after class }\end{array}$ & $\begin{array}{l}\text { Pre-learning before class and discussing } \\
\text { problems in class }\end{array}$ \\
\hline Time distribution in class & Spending most of time in teaching & $\begin{array}{l}\text { Spending most of time in discussing } \\
\text { among students }\end{array}$ \\
\hline Teaching contents in class & Teaching and imparting knowledge & Question- Answer study \\
\hline Application of teaching methods & Presenting learning contents & $\begin{array}{l}\text { Autonomous learning and cooperative } \\
\text { learning }\end{array}$ \\
\hline Teaching evaluation & Paper test & Evaluation from multiple aspects \\
\hline
\end{tabular}

The main distinction between the Traditional Classroom and the Flipped Classroom reflects the different roles of students and teachers in learning. In traditional classroom, teachers teach textbooks and students learn passively. While in the Flipped Classroom, students become the real master of learning and they acquire knowledge through their own efforts and discuss the problems in learning with teachers and classmates. Teachers become the instructor and stimulator of students' learning, instead of being the authority and owner of knowledge.

From the aspect of teaching methods in class, the Traditional Classroom takes the form of in-class teaching and after-class homework. In this way, students become "containers" of knowledge, listening to their teachers in class and finishing homework after class, therefore there are few interactions in class. While in the Flipped Classroom, students preview what they will learn in advance so that they have had certain knowledge about it. In the course of the class, they can discuss the topics about the text designed by the teacher and deal with the unsolved problems in their preview during the process.

In the aspect of time distribution in class, the Traditional Classroom and the Flipped Classroom vary a lot. In Traditional Classroom, teachers spend most of time in teaching, while most of time is spent on discussing between students and teachers in the Flipped Classroom. In Jonathan Bergman and Aaron Sams' book Flip Your Classroom: Reach Every Student in Every Class Every Day (2014), it is mainly about the time distribution:

\begin{tabular}{|l|l|l|}
\hline \multicolumn{1}{|c|}{ Classroom Mode } & $\begin{array}{l}\text { Traditional } \\
\text { Classroom }\end{array}$ & $\begin{array}{l}\text { Flipped } \\
\text { Classroom }\end{array}$ \\
\hline Teaching Activities & $5 \mathrm{mins}$ & $5 \mathrm{mins}$ \\
\hline Pre-class activities & $15 \mathrm{mins}$ & - \\
\hline Chealing with homework & & $10 \mathrm{mins}$ \\
\hline Teaching for understanding on last night's teaching video & $25 \mathrm{mins}$ & - \\
\hline Group discussion/presentation & - & $20 \mathrm{mins}$ \\
\hline Evaluation & & $10 \mathrm{mins}$ \\
\hline
\end{tabular}

In the aspect of teaching contents in class, in the traditional classroom explaining the language points becomes the major task. And most teachers regard teaching textbooks as their only target. Language points have been the center of any teaching activities and the students' passively learn has been the center of all learning activities. Therefore, classrooms have been a place where teachers master everything while students study just for tests. The Traditional Classroom regards knowledge itself as the target of research (Guo Yuanxiang, 2005). The Flipped Classroom treats knowledge from the perspective of human development, regarding students as the real cognitive subject of knowledge, which means that students are not the warehouse that store knowledge.

In Traditional Classroom, the teacher is the authority of knowledge, and the presentation of teaching contents 
becomes the major task. The Flipped Classroom makes students become the master of learning.

Teaching evaluation is a key element in each teaching mode. The evaluation methods and its value of different teaching modes also vary a lot. In Traditional Classroom, the teachers' major task is to explain languages points and the students' major learning activity is to master knowledge. The examination papers are still the main teaching evaluations. Grades are the only standard to examine the students' ability. For the so-called Quality-Oriented Education, the Educational Department tries hard to change evaluation methods under the traditional teaching models. However there are few essential changes in the evaluation methods. New Curriculum Reform aims to emphasize the thorough development of students' knowledge, skills, methods, emotional attitudes and values. The traditional paper test can only evaluate what students have grasped, ignoring other aspects. The Flipped Classroom doesn't totally criticize the traditional examination paper, and it serves for the teachers to know how much knowledge the students have mastered. In addition, the Flipped Classroom gives a comprehensive evaluation of students from multiple aspects.

\section{Previous Studies on the Flipped ClassRoom Abroad and at Home}

\section{A. Studies on the Flipped Classroom Abroad}

The Flipped Classroom originated from two chemistry teachers named Jonathan Berman and Aaron Sams, who worked in an America woodland park school. In 2007, they added explanation to the courseware and recorded teaching videos by recording software. And those videos were uploaded to the Internet for students who are unable to be in the classes for several reasons. The two teachers' innovative teaching practice made this method a new teaching mode, and received praise from more and more teachers and students. Up to now, the Flipped Classroom becomes a popular new teaching mode in America and the whole world.

The three reasons why the Flipped Classroom gained so much praise and became popular are as follows: 1. High technology is the guarantee for the Flipped Classroom, and students can watch autonomous learning videos freely after class. 2. The economic situation of America offers a market for the Flipped Classroom. The Flipped classroom is economically successful concerning with the current situation since American financial situation can't offer the change from the large classroom to individual teaching (Dan Berrett, 2012; Hunt Marc w, 2013). 3. Internet videos are widely used in teaching.

Nowadays, many schools in America have started to adopt the Flipped Classroom. In America the Flipped Classroom centralizes in middle and primary school and focuses on science subjects like math, physics and science. The teaching process promotes the recognition of scholars and teachers for the Flipped Classroom. They summarized the advantages and disadvantages of the Flipped Classroom according to their teaching practice.

Among those scholars and teachers, most of them believe that the Flipped Classroom can get better effects than the traditional one. For example: Upside Down and Inside Out: Flip Your Classroom to Improve Student Learning (Fulton, Kathleen. 2012), Flip Your Classroom: Reach Every Student in Every Class Every Day (Aaron Sams, Jonathan Bergmann. 2014), Flipping the Classroom-Unconventional Classroom: A Comprehensive Guide to Constructing the Classroom of the Future (Matthew Ogles, Brent Bogan. 2014), The Flipped Classroom - A Teacher's Complete Guide: Theory Implementation and Advice (Dr. K. Plunkett Jacob Beckerman. 2014), Evidence on Flipped Classroom is Still Coming in (Bryan Goodwin, Kirsten Miller. 2013), Flip Your Students' Learning (Aaron Sams, Jonathan Bergmann. 2013), 10 Reasons to Flip (Kathleen P. Fulton. 2012), How 'Flipping' the Classroom Can Improve the Traditional Lecture (Dan Berrett. 2012), The Flipped Classroom: A Survey of the Research (Jacob Lowell Bishop. 2013). All these articles point out students learn the teaching video at their own pace, and they will turn to the web and social media for information according to their needs. Doing "homework" in class gives teachers better insight into student difficulties and learning styles, and it gives teachers more opportunities to provide feedback to students. Thus the classroom time can be used more effectively and creatively. It turns out student achievement is increasing, so is interest and engagement. In addition, Teachers improve professional development by watching each other's videos and learning from each other. Meanwhile Fulton Kathleen and Kathleen P. Fulton think the Flipped Classroom requires for a higher demand for teachers' teaching design capabilities, for teachers need more time to design the courses. In Jonathan Bergmann and Aaron Sams' articles, they consider that the Flipped Classroom makes students become the center of the courses, and it requires the learners to make schedules for themselves as well as being responsible for themselves. Dan Berrett (2012) believes that the Flipped Classroom is good for students to improve their learning abilities, motivation and getting higher grades compared with the traditional one. The Flipped Classroom offers more interactions and communications between teachers and students, whilst also allowing students to be more willing to join in the classes.

Although the Flipped Classroom has lots of advantages, many scholars and teachers harbor their doubt in the teaching practice. The authors of The Flipped Classroom Strategy: What is it and how can it best be used? (Milman, Natalie B. 2012), Five Reasons I am not Flipping over the Flipped Classroom (Lisa, Nielsen. 2012) and Evidence on Flipped Classroom is still Coming in (Bryan Goodwin, Kirsten Miller. 2013) come up with the idea that in its practice there are lots of drawbacks: students may skip the materials entirely; the quality of teaching videos is different because of the difference in the maker's ability; students may benefit a little from the teaching videos and they don't make full use of the intime classes.

Whether the teaching effects can be improved or not lies on the design of teaching contents and teaching activities. However, the authors of The Flipped Classroom Strategy: What is it and how can it best be used? (Milman, Natalie B. 
2012), and How Flipping the Classroom Can Improve the Traditional Lecture (Dan Berrett. 2012) concentrate on the importance of teachers to the Flipped Classroom. More scholars believe, without scientific design, only inverting the teaching time and improving traditional teaching methods with technology did not change the essence of learning.

\section{B. Theoretical Studies on Flipped Classroom at Home}

Compared with the Flipped Classroom abroad, more theoretical researches are presented than the practices. The author searches "English Flipped Classroom" as keywords in CNKI, by the end of July 4, 2019, there are 4324 relevant papers. Its study mainly started from 2013, and there are only 6 papers in 2013. However, in 2014 there are 95 papers, and in 2015 there are 483 papers, while in 2016 there are 1054 papers, 1125 in 2017, by 2018 the number of papers is 1066, which fully shows the Flipped Classroom in China has aroused large attention and has rapid development.

The Chinese scholars pay more attention to the research of teaching design. Study on the Key Factors of the Flipped Classroom Teaching Mode discusses several important factors in implementing the Flipped Classroom, namely the design of the teaching videos and classroom activities, together with the construction of the individual cooperative learning environment and so on(Zhang Jinlei, 2013). Mr. Zhang, in the paper The Exploration of the Flipped Classroom Teaching Mode summarizes the characteristics and the design of the Flipped Classroom (Zhang Yunfeng, 2013). He believes that the teaching design process mainly covers three parts as the design of teaching videos before class, targeted training and designed classroom activities. In Wang Hong's paper The Design of Flipped Classroom Teaching Mode-Analysis Based on Typical Cases at Home and Abroad, she constructs the Flipped Classroom teaching mode by analyzing the domestic and foreign typical cases (Wang Hong, 2013). In an article Design and Application of Task-based Flipped Classroom Teaching Mode, the author analyzes the advantages and the facing challenges of the Flipped Classroom, and then constructs the teaching mode named "problem-core and task-driven" (Li Hailong, 2013). These previous studies have played an important role in promoting the widespread practice of the Flipped Classroom in China, and also laid the foundation for the relevant practical research in China.

\section{Practical Studies on Flipped Classroom at Home}

In recent years, with the development of the Flipped Classroom teaching mode in foreign schools, some Chinese schools begin to practice the Flipped Classroom teaching mode, according to Chinese actual teaching situation. For example, Chongqing Jukui Middle School, Shenzhen Nanshan Experimental Middle School, Shanxi Yuncheng Xinjiang Middle School, and Jiangsu Mudu Senior High School and so on. Chongqing Jukui Middle School and Shenzhen Nanshan Experimental School are the pioneers, whose modes set good examples in the field of domestic education (Zhong Xiaoliu, 2013).

1. “3456” Teaching Mode in Chongqing Jukui Middle School

In 2011, Chongqing Jukui Middle School learns from foreign outstanding cases in the Flipped Classroom Teaching Mode and makes appropriate adjustments according to the actual situation of the school, and then sums up the "Three, Four, Five, and Six" mode. Three refers to the Three Flips (flip the teaching objectives; flip the teaching conception; and flip the teaching methods), Four refers to the Four parts before class (teachers make teaching plan; teachers make teaching video; students preview; and teachers get to know how much students master), Five refers to the Five steps in class (students' mutual cooperation; teachers' illustration; students' more practice; students' self-correction; and teachers' evaluation), and Six refers to the Six advantages (teachers teach less, students learn more; teachers can help students one by one; teachers get to know how much students master in time; teachers adjust measures to different levels of students; teachers enrich teaching context; and teachers reduce the burdens). After a period of trial experiment, the school conducts a questionnaire in the experimental class to examine the effect of the Flipped Classroom Teaching Mode. The experiment results show that most students prefer this kind of new teaching mode and they think the new teaching mode improves their interest as well as enhance their confidence. Chongqing Jukui Middle school perfect the teaching mode instead of completely copying the foreign Flipped Classroom, therefore it can implement the Flipped Classroom Teaching Mode well (Wang Hong, 2013).

2. Shenzhen Nanshan Experimental Middle School

With development of the Cloud Computing environment, Shenzhen Nanshan Experimental Middle School implements the Flipped Classroom Teaching Mode with the information technology integration strategy in 2012. The school also learns from foreign experience to implement localization practice to achieve the depth of teaching methods. The results are published in the Southern Education Times, which drew widespread praise amongst scholars and teachers.

Combining with the different characteristics of their own schools in China, some schools have explored the suitable Flipped Classroom Teaching Mode for themselves. It also greatly promotes the development of the Flipped Classroom Teaching Mode in China.

\section{Studies on English Flipped Classroom at Home}

Compared with a small amount of research studies on senior high school in China, most studies concentrate on application of Flipped Classroom in College. These studies are On Discussion of the College English Flipped Classroom Teaching Mode (Fan Xiuli, 2013), On the Construction of Flipped Classroom Mode in College English (Fu Lei, 2014), Feasibility Analysis on the Application of Micro-class Based "Flipped Classroom" Mode in College English Teaching (Lu Haiyan, 2014), Flipped Class Mode and Its Application to College English Teaching (Cui Yanhui, Wang Yi, 2014), 
The Application of the Flipped Classroom in College Teaching (Wang Binhong, 2014), The Application Research of Flipped Classroom in University Teaching - A case study on professional English of Educational Technology (Wang Xiaodong, Zhang Chengjingzi, 2014). They all focus on the present situation of the college English teaching, and trying to improve students' interests and capabilities in English learning research. Compared with the Flipped Classroom in college, little research, especially in English class has been conducted in junior and senior high school. In this thesis, the author tries to flip the English reading class in senior high school.

\section{CONCLUSION}

Compared with the traditional teaching mode, the Flipped Classroom has changed teachers' role, students' role, teaching methods, time distribution, teaching contents, application of teaching methods and teaching evaluation. However, according to the studies on the situation of the Flipped Classroom at home and abroad, there are some achievements in the theory and experiential cases, but there are still some disadvantages. For instance, most studies concentrated on logical subjects like math, science and physics. In China, most related studies focus on the introduction and exploration of the Flipped Classroom, therefore there is much more theoretical research than practical research. Few studies have been focusing on language teaching, especially on English reading class in senior high schools. The Flipped Classroom is a totally new teaching conception and has an abundance of advantages compared with the traditional teaching model.

\section{REFERENCES}

[1] Aaron Sams, Jonathan Bergmann. (2013). Flip Your Students' Learning. Educational Leadership, 3, 16-20.

[2] Aaron Sams, Jonathan Bergmann. (2014). Flip Your Classroom: Reach Every Student in Every Class Every Day. Beijing: China Youth Press.

[3] Benjamin S. Bloom. (1986). Mastery learning assumes that it is within nearly every student's capacity to master any given instructional task. Fujian: Fujian Education Press.

[4] Benjamin S. Bloom, Qiu Yuan. (1987). Educational Evaluation. Shanghai: East China Normal University Press.

[5] Bryan Goodwin, Kirsten Miller. (2013). Evidence on Flipped Classroom is Still Coming in. Educational Leadership, 6, 78-80.

[6] Cui Yanhui, Wang Yi. (2014). Flipped Class Model and Its Application to College English Teaching. Journal of Inner Mongolia University of Finance and Economics, 11, 116-120.

[7] Dan Berrett. (2012). How 'Flipping' the Classroom Can Improve the Traditional Lecture. Education Digest, $2,36-41$.

[8] Dr. K. Plunkett Jacob Beckerman. (2014). The Flipped Classroom - A Teacher's Complete Guide: Theory Implementation and Advice. Washington State: Amazon Digital Services LLC.

[9] Fan Xiuli. (2013). On the Flipped Classroom Model in College English. Journal Chifeng University, 11, 271-272.

[10] Fu Lei. (2014). On the Construction of Flipped Classroom Mode in College English. Journal of Inner Mongolia University of Finance and Economics, 6, 113-114.

[11] Fulton, Kathleen. (2012). Upside Down and Inside Out: Flip Your Classroom to Improve Student Learning. Learning \& Leading with Technology, 6, 12-17.

[12] Guo Yuanxiang. (2005). The Turning of Curriculum Knowledge View under the New Curriculum. Global Education, 4, 15-20.

[13] Hunt Marc W. (2013). Video \& Sound Production: Flip out! Game on! Alexandria Techniques, 1, 36-38.

[14] Jacob Lowell Bishop. (2013). The Flipped Classroom: A Survey of the Research. 120th ASEE Annual Conference \& Exposition.

[15] Kathleen P. Fulton. (2012). 10 reasons to flip. New styles of instruction, 2, 20-24.

[16] Li Hailong. (2013). Design and Application of Task-based Flipped Classroom Teaching Model. Modern Educational Technology, 9, 46-51.

[17] Lisa, Nielsen. (2012). Five reasons I am not flipping over the flipped classroom. Tech \& Learning, 9, 15-18.

[18] Lu Haiyan. (2014). Feasibility Analysis on the Application of Micro-class Based“Flipped Classroom” Mode in College English Teaching. Technology Enhanced Foreign Language Education, 7, 33-36.

[19] Matthew Ogles, Brent Bogan. (2014). Flipping the Classroom-Unconventional Classroom: A Comprehensive Guide to Constructing the Classroom of the future. New York: U.C. Publishing.

[20] MaureenLage, Glenn Platt, Michael Treglia. (2000). Inverting the classroom: A gateway to creating an inclusive learning environment. Journal of Economic Education, 31, 30-43.

[21] Milman, Natalie B. (2012). The flipped classroom strategy: What is it and how can it best be used? Greenwich: Distance Learning, 3, 85-87.

[22] Qu Baokui. (1988). Educational Anthology: Teaching. Beijing: People's Education

[23] Wang Binhong. (2014). The Application of Flipped Classroom in College English Teaching. College English, 1, 9-12.

[24] Wang Hong. (2013). The Design of Flipped Classroom Teaching Model-Analysis Based on Typical Cases at Home and Abroad. Modern Educational Technology, 8, 5-10.

[25] Wang Xiaodong, Zhang Chenjingzi. (2011). The Application Research of Flipped Classroom in University Teaching-A case study on professional English of Educational Technology. Modern Educational Technology, 8, 11-16.

[26] Zhang Futao. (2014). Flipped Class Model: Theoretical Research and Practical Exploration. Jinan: Shandong Friendship Press.

[27] Zhang Jinlei. (2013). An Analysis on the Key Factors of Flipped Classroom Teaching Model. Distance Education in China, 10, 59-64.

[28] Zhang Renxian. (2014). Flipping Classroom Model and Teaching Transition. Beijing: World Knowledge Press.

[29] Zhang Yunfeng, Hu Qing. (2013). The Explorer of the Turnover of Classroom Teaching Mode. Time Education, 3, $105-106$.

[30] Zhong Xiaoliu, Song Shuqiang, Jiao Lizhen. (2013). Instructional Design Based on the Idea of the Flipped Classroom in ICT 
Environment. Open Education Research, 1, 58-64.

Fei Deng was born in Sichuan, China in 1981. He is currently an associate professor in the School of Foreign Languages, Sichuan University of Arts and Science, Sichuan, China. He has finished 4 scientific research subjects and published 22 papers in journals. He is a member of Sichuan Applied Foreign Languages Institute. His research interests include Foreign Language Teaching, and Translation Theory and Practice. This article is a periodic achievement of A Study on Flipped College English Teaching Based on Knowledge Internalization in Sichuan University of Arts and Science (SCWYH19-14), sponsored by Sichuan Foreign Language Literature Research Center \& Shanghai Foreign Language Education Press. 